\title{
Sustainability Adoption through Sustainable Human Resource Management: A Systematic Literature Review and Conceptual Framework
}

\author{
Anil Kumar \\ Guildhall School of Business and Law, \\ London Metropolitan University, London, UK. \\ Corresponding author: anilror@gmail.com \\ Preeti Bhaskar \\ Department of Business Studies, \\ Ibra College of Technology, Oman. \\ E-mail: preeti.bhaskar52@gmail.com \\ Simon Peter Nadeem \\ Centre for Supply Chain Improvement, The University of Derby, \\ Kedleston Road Campus, Derby, DE22 1GB, UK. \\ E-mail: S.nadeem@derby.ac.uk

\section{Mrinal Tyagi} \\ Centre for Supply Chain Improvement, The University of Derby, \\ Kedleston Road Campus, Derby, DE22 1GB, UK. \\ E-mail: mrinal1tyagi@gmail.com \\ Jose Arturo Garza-Reyes \\ Centre for Supply Chain Improvement, The University of Derby, \\ Kedleston Road Campus, Derby, DE22 1GB, UK. \\ E-mail: J.Reyes@ derby.ac.uk
}

(Received May 12, 2020; Accepted August 2, 2020)

\begin{abstract}
Sustainability is a key aspiration of most businesses as they face pressure from regulatory authorities as well as consumer demand for sustainable products. Sustainability discussion often revolves around the areas of raw materials, product and process design and innovation. However, the role of human resources is least discussed in this regard. This research utilises a systematic literature review approach to explores the concept of Sustainable Human Resource Management (SHRM) and identifies the indicators, drivers, barriers, and benefits of SHRM adoption. Based on the findings, an integrated conceptual framework that can be utilised by organisations for developing a long-lasting sustainability adoption through SHRM is proposed.
\end{abstract}

Keywords- Sustainable human resource management, Human resources and sustainability, Green human resource management, Environmental Human resource management.

\section{Introduction}

Sustainable development is a very important concept in the business world today, especially with a focus to enable individuals and companies to meet their current needs without hampering the environment for future generations (Nadeem et al., 2017; Garza-Reyes et al., 2019) . However, it 
International Journal of Mathematical, Engineering and Management Sciences

Vol. 5, No. 6, 1014-1031, 2020

https://doi.org/10.33889/IJMEMS.2020.5.6.078

has been observed that traditional market models focus on the short-termed efficient and effective utilisation of natural, social, and human resources in organisations rather than focusing on a longterm multifaceted and dynamic knowledge-based economy. Over the last decades, Sustainability has been the subject of thought and reflection in the field of management. Ehnert et al. (2014) defined sustainability as a concept for providing new solutions and making economic systems and organisations more viable over the long term with less harm to society and the world's well-being. While often the sustainability is assumed to be only related to the management of materials and production techniques, Human resource management (HRM) has a great role to play in its practical assimilation. Sustainability shifts the focus towards the capability of HRM to sustain the HR base from within and for organisational viability. Recently, studies related to sustainability and HRM seem to have captured the interest of researchers. Sustainable human resource management (SHRM) can be well-thought-out as a design for the employment relationship, and a contribution to sustainable development (Gollan, 2000; Zaugg et al., 2001; Ehnert, 2009a). Ehnert (2009b) highlights the need for more SHRM practices and regards sustainability as having a strategic potential for HRM. Ehnert (2009b) defines SHRM as "the pattern of planned or emerging human resource deployments and activities intended to enable a balance of organisational goal achievement and reproduction of the human resource base over a long-lasting calendar time and to control for negative impact on the human resource base".

This study contributes to the existing literature on SHRM by providing a systematic review of the literature on the topic of SHRM and proposing a conceptual framework for sustainability adoption through SHRM. The paper examines the concept of SHRM through a systematic literature review and identifies the indicators, drivers, barriers, and benefits of SHRM adoption to benefit practitioners, academics, and researchers. The rest of the paper is structured in 6 sections. Section 2 presents the systematic literature review; Section 3 discusses the concept of SHRM while Section 4 presents the benefits and barriers to SHRM adoption. On the other hand, Section 5 introduces the developed conceptual framework developed; finally, Section 6 provides the conclusions, limitations and future research directions derived from the study

\section{Systematic Literature Review Approach}

To accomplish the aim of this study, the systematic literature review (SLR) approach followed by Garza-Reyes (2015) was adopted. Table 1 presents the 5 phases that the SLR went through.

Table 1. Systematic literature review phases

\begin{tabular}{|c|c|c|c|}
\hline S. No. & SLR Phase & Objective and methods used & $\begin{array}{c}\text { Article's } \\
\text { section }\end{array}$ \\
\hline 1. & $\begin{array}{l}\text { Scope } \\
\text { Formulation }\end{array}$ & $\begin{array}{l}\text { Defining the scope of research to be in the bounds of Sustainable human resource } \\
\text { management }\end{array}$ & 1 \\
\hline 2. & $\begin{array}{l}\text { Locating } \\
\text { Studies }\end{array}$ & $\begin{array}{l}\text { To locate studies, the following criteria were defined: } \\
\text { - } \quad \text { Duration: 1984-2018 } \\
\text { Electronic databases such as Elsevier, Science Direct, Sage, JSTOR, Emerald, Taylor } \\
\text { and Francis, Inderscience, IGI, EBSCO, John Willey, and Springer were explored. } \\
\text { Keywords: sustainable human resource management, Human Resources and } \\
\text { Sustainability, Green Human resource management, and environmental Human } \\
\text { resource management }\end{array}$ & 2 \\
\hline 3. & $\begin{array}{l}\text { Study } \\
\text { Selection }\end{array}$ & $\begin{array}{l}\text { Published research papers with sustainability aspect (environmental, social and economic) } \\
\text { and its implementation in HRM, were selected. }\end{array}$ & 2 \\
\hline 4. & $\begin{array}{l}\text { Analysis \& } \\
\text { Synthesis }\end{array}$ & $\begin{array}{l}\text { Identifying the indicators, drivers, barriers, and benefits of SHRM adoption to benefit } \\
\text { practitioners, academics, and researchers. }\end{array}$ & $3 \& 4$ \\
\hline 5 & $\begin{array}{l}\text { Drawing the } \\
\text { conceptual } \\
\text { framework }\end{array}$ & Developing a conceptual framework for sustainability adoption through SHRM. & 5 \\
\hline
\end{tabular}


International Journal of Mathematical, Engineering and Management Sciences

Vol. 5, No. 6, 1014-1031, 2020

https://doi.org/10.33889/IJMEMS.2020.5.6.078

The SLR included papers published in peer-reviewed journals from 1984 to 2018 . The year 1984 was considered as the base year as no significant study on SHRM was found before that year. Nearly all research papers related to SHRM, green HRM, triple-bottom-line, Strategic HRM, HR $\&$ sustainability were acknowledged. Multiple databases such as Elsevier, Science Direct, Sage, JSTOR, Emerald, Taylor and Francis, Inderscience, IGI, EBSCO, John Willey, and Springer were used to search for the literature. Only those papers with sustainability aspect (environmental, social and economic) and its implementation in HRM were selected. The initial search was conducted using the following keywords: sustainable human resource management, Human Resources and Sustainability, Green Human resource management, and environmental Human resource management. Keywords related to sustainability and HRM were used through different combinations. This search yielded 1,105 papers. After removing duplications, the number of papers was reduced to 586. A careful reading of abstracts led to the further elimination of 320 papers. 266 papers were then thoroughly assessed to ensure their relevance to the focus of this research, from which 163 papers were finally selected.

\section{Sustainable Human Resource Management}

SHRM is an impending subject. Nevertheless, very little research has been conducted on this subject due to its emerging stage (Sosik et al., 2002; Wehling et al., 2009). As per its definition, Jarlstrom et al. (2018) characterise that the basic concept underlying the discussion of SHRM is that firms seek different kinds of outcomes to satisfy their stakeholders' expectations. These outcomes may be economic, social, human, and ecological, and firms often seek them simultaneously even though one or two may be more important to an organisation than the others. Many organisations are willingly to report their economic, social and ecological sustainability performance (Schaltegger and Wagner, 2006; Sena and Shani, 2008).

\subsection{Models of Sustainable Human Resource Management}

SHRM is constantly developing and the literature proposes some useful models. A model by Zaugg et al. (2001) is academically and empirically validated. In this model, SHRM is related to employees acting in a self-responsible way and participating in the decision making of the organisation. The success of SHRM is measured from the organisational and employee perspectives. Economic value-added, organisational flexibility, and viability contribute to the organisation's perspective whereas employee employability, well-being, and self-responsibility contribute to the employee's perspective. Ehnert (2009c) focuses on sustainable resource management approach, which points out the dependence of organisations on the survival of their organisational environments. He adopts three theoretical perspectives - the stakeholder theory, resource-based view, and systems theory. Zaugg (2001) represents the Swiss approach which depends on empirical research on the understanding of sustainability and HRM in practice. It has been extended into a systematic conceptualisation of SHRM grounded in conceptual and qualitative case research. Cohen et al. (2012) recognise three characteristics of equity, well-being and employee development, and five prerequisites of compliance, governance, ethics, culture and leadership for SHRM. de Prins et al. (2014) proposed "Respect, Openness and Continuity" (ROC) model of SHRM. Respect for the internal stakeholders in the organisation i.e. employees, Openness focuses on environmental awareness in the perspective of HR and Continuity focus on long-term approach in both economic and societal sustainability terms.

Gollan and Xu (2014) identify external and internal drivers for SHRM. External drivers include market, technology, changes required by regulations, and internal drivers include culture and customers, leadership and management style. Likewise, Kramar (2014) focuses on human 
International Journal of Mathematical, Engineering and Management Sciences

Vol. 5, No. 6, 1014-1031, 2020

https://doi.org/10.33889/IJMEMS.2020.5.6.078

resources sustainability and identifies external drivers such as market, technology, changes required by regulations and internal drivers, such as culture and customers, leadership and management style. Gollan and Xu (2014) explicitly identify outcomes of SHRM in terms of productivity and profit, employee satisfaction and commitment, employee development, equity and well-being whereas Kramar (2014) identify four types of outcomes such as organisational, social, individual, and ecological. He presents SHRM as the pattern of planned or emerging HR strategies/practices intended to enable the achievement of financial, social and ecological goals while simultaneously reproducing the HR base over the long term. It seeks to minimise the negative impacts on the natural environment, people and communities and acknowledges the critical enabling role of CEOs, middle and line managers, HRM professionals and employees in providing practices which are distinctive, consistent and reflect the consensus among decision-makers. With increasing pressure from stakeholders, concerns on the subject of environmental issues are highlighted and companies are driven to develop policies and programs to conduct environmentally sustainable business activities and act under the environmental regulations (Yadav et al., 2016). Table 2 shows the dimension of various SHRM models.

Table 2. Models of sustainable HRM

\begin{tabular}{|l|l|l|}
\hline Author & Model & Dimensions \\
\hline Tabatabaei et al. (2017) & $\begin{array}{l}\text { Sustainable HRM Model } \\
\text { based on BSC }\end{array}$ & $\begin{array}{l}\text { Sustainable HRM within strategic management, Sustainable HRM } \\
\text { strategies }\end{array}$ \\
\hline Kramar (2014) & Sustainable HRM & Sustainable work systems negative externalities \\
\hline de Prins et al. (2014) & $\begin{array}{l}\text { Respect, Openness, and } \\
\text { Continuity (ROC) model }\end{array}$ & $\begin{array}{l}\text { Respect for the employees, Environmental awareness in perspective on } \\
\text { HRM, Long-term approach (economic and societal sustainability and } \\
\text { individual employability) }\end{array}$ \\
\hline $\begin{array}{l}\text { Mariappanadar and } \\
\text { Kramar (2014) }\end{array}$ & $\begin{array}{l}\text { Sustainable HRM } \\
\text { "Harm" of efficiency-oriented HRM on stakeholders and }\end{array}$ \\
\hline $\begin{array}{l}\text { Ehnert et al. (2014) } \\
\text { Ehnert (2009c) }\end{array}$ & $\begin{array}{l}\text { Practice-Based Model for } \\
\text { Link }\end{array}$ & $\begin{array}{l}\text { Internal and external drivers, Sustainability objectives at the corporate } \\
\text { level, HR-related sustainability objectives and HR-related activities }\end{array}$ \\
\hline $\begin{array}{l}\text { Martin-Alcazar et al. } \\
\text { (2005) }\end{array}$ & Integrative model foramework for & $\begin{array}{l}\text { Human capital, Normative interpretations of sustainability, Efficiency } \\
\text { interpretations of sustainability }\end{array}$ \\
\hline Zaugg et al. (2001) & $\begin{array}{l}\text { Social responsibility, Efficiency, } \\
\text { understanding of sustainability. Relationship between HRM strategy } \\
\text { and corporate strategy }\end{array}$ \\
\hline
\end{tabular}

\subsection{Indicators of Sustainable Human Resource Management}

SHRM is defined as "those long-term oriented conceptual approaches and activities aimed at a socially responsible and economically appropriate recruitment and selection, development, deployment, and release of employees" (Thom and Zaugg, 2004). The Brundtland Commission asserts that sustainability can achieve objectives at three points including economic, environmental and social, without risking natural life conditions (Ehnert, 2009b). Several pieces of research have reported that Environmental, Social, and Economic Sustainability are main indicators and factors affecting human resource sustainability. Companies are increasingly connecting the dots between sustainability and its impact on their organisation. As a result, more and more organisations are seeking ways to transform themselves into a sustainable organisation by making a positive impact on economic, environmental and social. These impacts are also affecting HR sustainability. 
International Journal of Mathematical, Engineering and Management Sciences

Vol. 5, No. 6, 1014-1031, 2020

https://doi.org/10.33889/IJMEMS.2020.5.6.078

\subsubsection{Environmental Sustainability}

Environmental sustainability focuses on creating a safe environment and seeks to reduce the negative impact and focus on solving environmental issues. Organisations are concentrating on practising green management to improve their environmental performance (Jabbour and de-Sousa Jabbour, 2016; Udokporo et al., 2020). Several studies concentrating on green management and green HRM practices (Prasad, 2013; Sathyapriya et al., 2013; Mittal and Sangwan, 2014; Opatha and Arulrajah, 2014; Ahmad, 2015, Masri and Jaaron, 2017) have emphasised the association between green HR practices such as green recruitment and selection, green training and development, green performance management, green reward system, green cordial relations, and positive environmental performance. Guerci et al. (2016) found that green training and involvement, green performance and green compensation are significantly positive to environmental performance. Table 3 represents the environmental sustainability indicators for SHRM.

Table 3. Environmental sustainability indicators of SHRM

\begin{tabular}{|c|c|}
\hline Indicators & References \\
\hline Green job design & $\begin{array}{l}\text { Revill (2000), Daily and Huang (2001), Govindarajulu and Daily (2004), Jabbour and Santos } \\
\text { (2008b), Renwick et al. (2013), Opatha and Arulrajah (2014), Arulrajah et al. (2015), Tooranloo et } \\
\text { al. (2017) }\end{array}$ \\
\hline Green employment & Prasad (2013), Jackson et al. (2014), Ahmad (2015), Arulrajah et al. (2015), Tooranloo et al. (2017) \\
\hline Green selection & $\begin{array}{l}\text { Crosbie and Knight (1995), North (1997), Revill (2000), Jabbour and Santos (2008a), Renwick et } \\
\text { al. (2013), Chan et al. (2014), Opatha and Arulrajah (2014), Arulrajah et al. (2015), Deepak and } \\
\text { Prakash (2015), Jepsen and Grob (2015), Tooranloo et al. (2017), Wehrmeyer (2017) }\end{array}$ \\
\hline $\begin{array}{l}\text { Green performance } \\
\text { evaluation }\end{array}$ & $\begin{array}{l}\text { Milliman and Clair (1996), Prasad (2013), Renwick et al. (2013), Jackson et al. (2014), Opatha and } \\
\text { Arulrajah (2014), Ahmad (2015), Arulrajah et al. (2015), Tooranloo et al. (2017), Wehrmeyer (2017) }\end{array}$ \\
\hline Green training & $\begin{array}{l}\text { Cook and Seith (1992), North (1997), Jabbour (2013), Prasad (2013), Renwick et al. (2013), Chan } \\
\text { et al. (2014), Jackson et al. (2014), Opatha and Arulrajah (2014), Arulrajah et al. (2015), Guerci et } \\
\text { al. (2016), Tooranloo et al. (2017) }\end{array}$ \\
\hline $\begin{array}{l}\text { Green reward system } \\
\text { management }\end{array}$ & $\begin{array}{l}\text { Bhushan and Mackenzie (1992), Crosbie and Knight (1995), Berry and Randinelli (1998), Ramus } \\
\text { (2001), Daily et al. (2003), Govindarajulu and Daily (2004), Prasad (2013), Renwick et al. (2013), } \\
\text { Jackson et al. (2014), Opatha and Arulrajah (2014), Ahmad (2015), Arulrajah et al. (2015), Jabbour } \\
\text { (2015), Guerci et al. (2016), Tooranloo et al. (2017) }\end{array}$ \\
\hline $\begin{array}{l}\text { Green compensation system } \\
\text { management }\end{array}$ & Ramus (2002), Fernández et al. (2003), Phillips (2007), Tooranloo et al. (2017) \\
\hline $\begin{array}{l}\text { Green health and } \\
\text { employees' safety } \\
\text { management }\end{array}$ & $\begin{array}{l}\text { Ditz et al. (1995), Beard and Hartmann (1997), Ahmad (2015), Arulrajah et al. (2015), Tooranloo et } \\
\text { al. (2017) }\end{array}$ \\
\hline $\begin{array}{l}\text { Green management of } \\
\text { employee discipline }\end{array}$ & $\begin{array}{l}\text { Wright and Mcmahan (2011), Renwick et al. (2013), Jackson et al. (2014), Opatha and Arulrajah } \\
\text { (2014), Arulrajah et al. (2015), Tooranloo et al. (2017) }\end{array}$ \\
\hline Employee green relations & Renwick et al. (2013), Ahmad (2015), Arulrajah et al. (2015), Tooranloo et al. (2017) \\
\hline Green recruitment & $\begin{array}{l}\text { Clarke (2006), Chartered Institute of Personnel and Development (2007), Phillips (2007), Stringer } \\
\text { (2010), Jabbour (2013), Renwick et al. (2013), Jackson et al. (2014), Arulrajah et al. (2015), Jepsen } \\
\text { and Grob (2015), Oates (2017), Wehrmeyer (2017) }\end{array}$ \\
\hline Green induction & $\begin{array}{l}\text { Crosbie and Knight (1995), North (1997), Revill (2000), Renwick et al. (2013), Opatha and } \\
\text { Arulrajah (2014), Arulrajah et al. (2015), Wehrmeyer (2017) }\end{array}$ \\
\hline Green HR planning & Arulrajah et al. (2015), Tooranloo et al. (2017) \\
\hline $\begin{array}{l}\text { Green policy } \\
\text { implementation }\end{array}$ & Ahmad (2015), Arulrajah et al. (2015), Tooranloo et al. (2017) \\
\hline
\end{tabular}

\subsubsection{Social Sustainability}

Social sustainability focuses on the welfare of current and future generations. To achieve these objectives, organisations focus on providing a good quality standard of life by reducing social inequality. Social sustainability occurs when the formal and informal processes, systems, 
International Journal of Mathematical, Engineering and Management Sciences

Vol. 5, No. 6, 1014-1031, 2020

https://doi.org/10.33889/IJMEMS.2020.5.6.078

structures, and relationships actively support the capacity of current and future generations to create healthy and liveable communities. Socially sustainable communities are equitable, diverse, connected, democratic, and provide a good quality of life. Table 4 represents the social sustainability indicators for SHRM.

Table 4. Social sustainability indicators of SHRM

\begin{tabular}{|l|l|}
\hline Indicators & References \\
\hline Social infrastructure & Ahmad and Schroeder (2002), Chan and Lee (2008), Tooranloo et al. (2017) \\
\hline $\begin{array}{l}\text { The availability of } \\
\text { career opportunities }\end{array}$ & Stiglitz (2002), Chan and Lee (2008), Tooranloo et al. (2017) \\
\hline Accessibility & Smith (2000), Tooranloo et al. (2017), Yeh and Ng (2017) \\
\hline $\begin{array}{l}\text { Ability to fulfil the } \\
\text { psychological needs }\end{array}$ & $\begin{array}{l}\text { Ahmad and Schroeder (2002), Turkington and Sangster (2006), Chan and Lee (2008), Daily et al. (2012), } \\
\text { Mampra (2013), Aragon-Correa et al. (2015), Tooranloo et al. (2017) }\end{array}$ \\
\hline Social justice & Dempsey et al. (2011), Tooranloo et al. (2017) \\
\hline $\begin{array}{l}\text { Social sustainability } \\
\text { design }\end{array}$ & Bramley et al. (2009), Dempsey et al. (2011), Tooranloo et al. (2017) \\
\hline $\begin{array}{l}\text { Corporate social } \\
\text { responsibility }\end{array}$ & Peneda Saraiva and Serrasqueiro (2007), Crane et al. (2008), Teck Hui (2008), Tooranloo et al. (2017) \\
\hline Social sustainability & Griessler and Littig (2005), Bramley et al. (2009), Dempsey et al. (2011), Tooranloo et al. (2017) \\
\hline
\end{tabular}

\subsubsection{Economic Sustainability}

Economic sustainability is associated with cost reduction, saving valuable resources for future generations, and better management of resources (Munasinghe, 1993; Garza-Reyes et al., 2019; Nadeem et al., 2019). SHRM treats sustainability as a mutual benefit for all stakeholders' groups and as a contribution to long economic sustainability. According to Nadeem et al. (2018) sustainability is the modality of development that enables economic and social progress, without destroying their environmental resources while making ethically acceptable, morally fair, socially and economically sound developments. Table 5 represents the economic sustainability indicators for SHRM.

Table 5. Economic sustainability indicators of SHRM

\begin{tabular}{|l|l|}
\hline Indicators & References \\
\hline HR efficiency & Copus and Crabtree (1996), Youndt et al. (1996), Tooranloo et al. (2017) \\
\hline Re-engineering/ restructuring & Love and Gunasekaran (1997), Tooranloo et al. (2017) \\
\hline Cost reduction strategy & Hanegraaf and Biewinga (1998), Tooranloo et al. (2017) \\
\hline $\begin{array}{l}\text { Senior management } \\
\text { commitment }\end{array}$ & Tisdell (1996), Glaser and Diele (2004), Tooranloo et al. (2017) \\
\hline Development of facilities & Tisdell (1996), Vincent (1997), Tooranloo et al. (2017) \\
\hline Macroeconomic policies & $\begin{array}{l}\text { Copus and Crabtree (1996), Vincent (1997), Hanegraaf and Biewinga (1998), Epstein (2008), } \\
\text { Tooranloo et al. (2017) }\end{array}$ \\
\hline Employment guarantee & Glaser and Diele (2004), Basu et al. (2009), Jha et al. (2013) \\
\hline
\end{tabular}

\section{Benefits of Adopting Sustainable Human Resource Management}

SHRM will enable organisations to balance conflicting expectations from different stakeholders such as employees, vendors, customers, shareholders, government, and communities by ensuring that they create a positive impact on organisational, environmental and financial performance. SHRM benefits can be measured by evaluating organisational, social, individual and ecological performance. Measures would need to evaluate outcomes such as quality of the employment 
International Journal of Mathematical, Engineering and Management Sciences

Vol. 5, No. 6, 1014-1031, 2020

https://doi.org/10.33889/IJMEMS.2020.5.6.078

relationship, health, and wellbeing of the workforce, employee productivity, quality of relationships at work, potential employer, being recognised among a range of potential sources of labour (social), job satisfaction, employee motivation, work-life balance (individual), use of resources, such as energy, paper, water, production of green products and services and costs associated with work travel (ecological).

Business stakeholders such as employees, creditors, investors, shareholders, consumers, regulators, and the public are further aware and put pressure on companies' environmental performance (Ilinitch et al., 1998; Molina-Azorín et al., 2009). Several measurement systems were introduced by the companies namely, environmental rating matrices, the corporate environmental scorecard, and corporate environmental reports to evaluate environmental performance (Ilinitch et al., 1998), but relatively they ensure their financial growth (Molina-Azorínet al., 2009). Companies with good social/human and ecological/environmental practices have a positive impact on their financial performance (Orlitzky et al., 2003; Branco and Rodrigues, 2006). Further, companies involved in ethical investments are also shown to have better financial performance compared to other companies (Collinson et al., 2008). Several studies have found the positive effect of green HRM practices on organisational and environmental performance. Green HRM practices in the form of green recruitment, green training, and green rewards can improve and support organisations' environmental performance and create competitive advantage (Renwick et al., 2013; Paille et al., 2014; Ahmad, 2015; Roy and Khastagir, 2016; Masri and Jaaron, 2017). Table 6 represents the benefits of adopting SHRM.

Table 6. Benefits of adopting SHRM

\begin{tabular}{|l|l|}
\hline Dimension & References \\
\hline Organisational performance & $\begin{array}{l}\text { Berry and Rondinelli (1998), Zaugg and Thom (2001), Gonzalez-Benito and Gonzalez-Benito } \\
\text { (2005), Chen et al. (2006), Driessen et al. (2013), Sawang and Kivits (2014) }\end{array}$ \\
\hline Environmental performance & $\begin{array}{l}\text { Gill et al. (1986), Banerjee (2002), Erdogan and Baris (2007), Crane et al. (2008), Jabbour and } \\
\text { Santos (2008a), Teixeira et al. (2012), Paille et al. (2013), Rawashdeh (2018), Yusoff and Nejati } \\
\text { (2019) }\end{array}$ \\
\hline Financial Performance & Bansal and Gao (2006), Yusoff and Nejati (2019) \\
\hline
\end{tabular}

\subsection{Drivers of Sustainable HRM Adoption}

To satisfy stakeholders demand and meeting market pressures, companies have started to implement sustainable business practices (Carmona-Moreno et al., 2004; Laudal, 2011; Kesidou and Demirel, 2012; Aguilera-Caracuel and Ortiz-de-Mandojana, 2013). Managers are increasing pressure on environmental performance programmes due to the number of environmental laws (Jones and Felps, 2013). These concerns and pressures are very crucial for the successful implementation of Green HRM practices. Seidel et al. (2010) emphasise that information technology, strategy, organisational support, traceability through information systems and motivation are a critical enabler for SHRM adoption. The human aspect is also identified as a critical enabler for adopting SHRM (Jabbour, 2013; Govindan et al., 2014; Longoni et al., 2014; Paille et al., 2014). Undoubtedly, investment in sustainability and socially responsible practices can produce several benefits for businesses. Sustainability adoption help in improving the reputation of businesses, increase their visibility, establish public trust, and help in becoming a socially responsible organisation. Laudal (2011) revealed that welfare activities, organisational work environment, and employee's performance contribute to sustainable practices and play a critical role in driving SHRM. Strict environmental laws also encourage companies to participate in 
sustainable practices (Laudal, 2011; Jones et al., 2014). Bansal and Gao (2006) highlighted that environmental performance programs are one of the most significant factors affecting quality of life, environmental sustainability, and the financial growth of the company. Table 7 represents drivers for SHRM adoption.

Table 7. Drivers for sustainable human resource management adoption

\begin{tabular}{|l|l|}
\hline Dimension & References \\
\hline $\begin{array}{l}\text { Environmental performance } \\
\text { programs }\end{array}$ & $\begin{array}{l}\text { Ilinitch et al. (1998), Brockhoff et al. (1999), Mostafa (2006), Jabbour and Santos (2008a), } \\
\text { Gadenne et al. (2009), Teixeira et al. (2012), Paillé et al. (2013), Wagner (2013) }\end{array}$ \\
\hline Stakeholders & $\begin{array}{l}\text { Ilinitch et al. (1998), Carmona-Moreno et al. (2004), Williamson et al. (2006), Kesidou and } \\
\text { Demirel (2012), Aguilera-Caracuelet and Ortiz-de-Mandojana (2013), Guerci and Shani (2013) }\end{array}$ \\
\hline Green HRM practices & Russo and Fouts (1997), Mehta and Chugan (2015), Mahmood et al. (2016) \\
\hline Human aspects & $\begin{array}{l}\text { Ramus (2001), Ramus (2002), Jabbour and Santos (2008a), Ehnert (2009d), Jabbour et al. (2010), } \\
\text { Boiral and Paille (2012), Graves et al. (2013), Jabbour (2013), Wolf (2013), Govindan et al. (2014), } \\
\text { Longoni et al. (2014), Paille et al. (2014) }\end{array}$ \\
\hline Environmental laws & Laudal (2011), Jones et al. (2014) \\
\hline $\begin{array}{l}\text { Welfare and employee } \\
\text { satisfaction }\end{array}$ & Laudal (2011) \\
\hline Meet market pressures & Laudal (2011) \\
\hline Employee performance & Laudal (2011) \\
\hline Working environment & Laudal (2011) \\
\hline
\end{tabular}

\subsection{Barriers in Adopting Sustainable Human Resource Management}

While the importance of and awareness for a move toward sustainability is increasing, its adoption faces some barriers and challenges. Conflicts in decisions with boards and/or management teams and the lack of employees' acceptance are major barriers/challenges (Gollan, 2000; Jafri, 2012). Seidel et al. (2010) identified that a lack of organisational support and lack of transparency negatively impact the adoption of sustainable practices. Organisations are also constrained on time and resources as well as lack of employee acceptance for implementing SHRM (Sweeney, 2009; Seidel et al., 2010; Fayyazi et al., 2015). Depending on the size of the company, implementation expenses become another major concern (Sweeney, 2009). Due to the absence of technical support and zero understanding of green policies among the employees, the organisation finds it difficult to implement SHRM (Rompa, 2011; Jafri, 2012; Fayyazi et al., 2015). Table 8 presents the barriers to SHRM adoption.

Table 8. Barriers to SHRM adoption

\begin{tabular}{|l|l|}
\hline Dimension & Reference \\
\hline $\begin{array}{l}\text { Lack of support from middle } \\
\text { management }\end{array}$ & Seidel et al. (2010), Paille et al. (2013), Harvey et al. (2013) \\
\hline Lack of time & Sweeney (2009), Seidel et al. (2010), Fayyazi et al. (2015) \\
\hline Lack of resources & Sweeney (2009), Fayyazi et al. (2015) \\
\hline Company size & Sweeney (2009) \\
\hline Board management decision & Sweeney (2009), Paille et al. (2013), Fayyazi et al. (2015) \\
\hline Manager decision & Sweeney (2009), Paille et al. (2013), Fayyazi et al. (2015) \\
\hline Lack of employee acceptance & $\begin{array}{l}\text { Harris and Ogbonna (1998), Hillary (2004), Murillo-Luna et al. (2007), Chan and Lee (2008), } \\
\text { Sweeney (2009), Linnenluecke and Griffiths (2010), Fayyazi et al. (2015) }\end{array}$ \\
\hline Lack of technical support & Rompa (2011), Fayyazi et al. (2015) \\
\hline $\begin{array}{l}\text { Lack of understanding of green } \\
\text { policies }\end{array}$ & Rompa (2011), Fayyazi et al. (2015) \\
\hline Implementation expenses & Rompa (2011), Jafri (2012), Fayyazi et al. (2015) \\
\hline Lack of comprehensive planning & Fayyazi et al. (2015) \\
\hline Staff pressure and resistance & Peng and Lin (2008) \\
\hline
\end{tabular}


International Journal of Mathematical, Engineering and Management Sciences

Vol. 5, No. 6, 1014-1031, 2020

https://doi.org/10.33889/IJMEMS.2020.5.6.078

\section{Sustainable Human Resource Management Framework for Sustainability Adoption}

With the identification of drivers, barriers, and benefits of SHRM, this section presents an integrated framework of SHRM. A conceptual model for SHRM framework for sustainability adoption is presented in Figure 1. This framework captures the Environmental, Social, and Economic Sustainability indicators of SHRM as well as the Organisational, Environmental, and Financial benefits of adopting SHRM. Since sustainability adoption is a continuous process, it needs continuous support from the drivers of SHRM. The identification of drivers (Environmental performance programmes, Stakeholders, Green HRM practices, Human aspects, Environmental laws, Welfare, and employee satisfaction, Market pressures, Employee performance, working environment) contributes to the easy adoption of SHRM practices in an organisation. The identification of barriers is vital so organisations can reduce the hurdles and benefits can be derived without much issue.

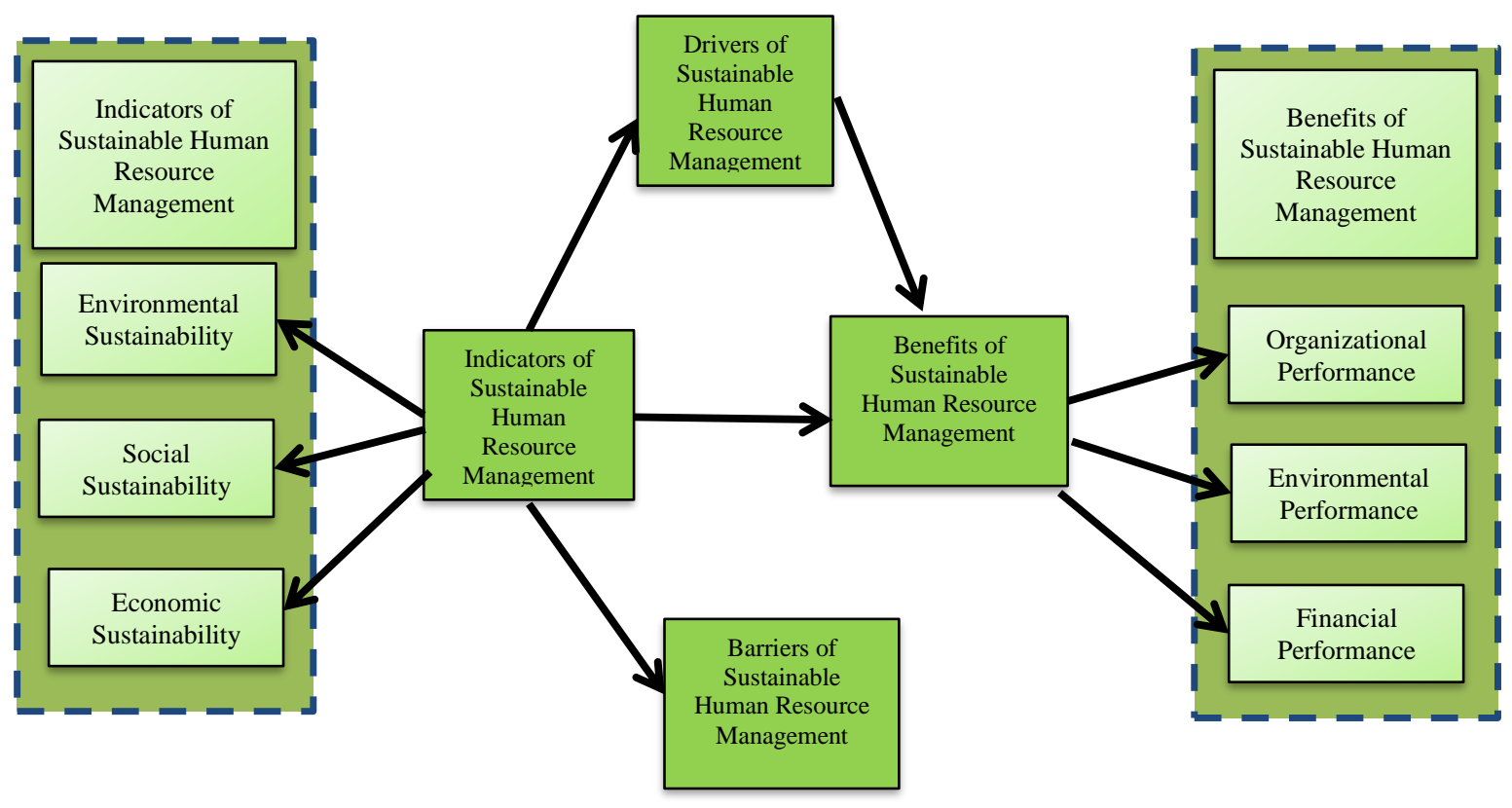

Figure 1. Proposal of SHRM framework for sustainability adoption

\section{Conclusions}

This study explored the concept of SHRM and its importance in sustainability adoption in an organisation. By adopting a systematic literature review approach, this study identifies the indicators, drivers, barriers and benefits of SHRM adoption. The process of sustainability adoption begins with the identification of indicators of SHRM and ends at deriving benefits. This research also provides an integrated conceptual framework that could be used for developing a long-lasting sustainability adoption through sustainable human resource management (SHRM). Like any other research, this research has certain limitations. At first, the research completely relies on secondary data. Further research can gather primary data for concurrent exploitation of the concept's value. Secondly, the research presents a conceptual framework which needs verification and validation. 
International Journal of Mathematical, Engineering and Management Sciences

Vol. 5, No. 6, 1014-1031, 2020

https://doi.org/10.33889/IJMEMS.2020.5.6.078

Furthermore, future research can deploy different methodological angles, such as qualitative and quantitative approaches to validate the research findings and implications.

\section{Conflict of Interest}

The authors confirm that there is no conflict of interest to declare for this publication.

\section{Acknowledgement}

The authors sincerely thank anonymous reviewers and the Editor-in-Chief for providing critical comments and suggestions for improving the quality of the paper.

\section{References}

Aguilera-Caracuel, J., \& Ortiz-de-Mandojana, N. (2013). Green innovation and financial performance: an institutional approach. Organization \& Environment, 26(4), 365-385.

Ahmad, S. (2015). Green human resource management: policies and practices. Cogent Business \& Management, 2(1), 1030817.

Ahmad, S., \& Schroeder, R.G. (2002). The importance of recruitment and selection process for sustainability of total quality management. International Journal of Quality \& Reliability Management, 19(5), 540550 .

Aragon-Correa, J.A., Martin-Tapia, I., \& de la Torre-Ruiz, J. (2015). Sustainability issues and hospitality and tourism firms' strategies: analytical review and future directions. International Journal of Contemporary Hospitality Management, 27(3), 498-522.

Arulrajah, A.A., Opatha, H.H.D.N.P., \& Nawaratne, N.N.J. (2015). Green human resource management practices: a review. Sri Lankan Journal of Human Resource Management, 5(1), 1-16.

Banerjee, S.B. (2002). Corporate environmentalism: the construct and its measurement. Journal of Business Research, 55(3), 177-191.

Bansal, P., \& Gao, J. (2006). Building the future by looking to the past: examining research published on organizations and environment. Organization \& Environment, 19(4), 458-478.

Basu, A.K., Chau, N.H., \& Kanbur, R. (2009). A theory of employment guarantees: contestability, credibility and distributional concerns. Journal of Public Economics, 93(3-4), 482-497.

Beard, C., \& Hartmann, R. (1997). Sustainable design: rethinking future business products. The Journal of Sustainable Product Design, 1(3), 18-27.

Berry, M.A., \& Rondinelli, D.A. (1998). Proactive corporate environmental management: a new industrial revolution. Academy of Management Perspectives, 12(2), 38-50.

Bhushan, A.K., \& MacKenzie, J.C. (1992). Environmental leadership plus total quality management equals continuous improvement. Environmental Quality Management, 1(3), 207-224.

Boiral, O., \& Paillé, P. (2012). Organizational citizenship behaviour for the environment: measurement and validation. Journal of Business Ethics, 109(4), 431-445.

Bramley, G., Dempsey, N., Power, S., Brown, C., \& Watkins, D. (2009). Social sustainability and urban form: evidence from five British cities. Environment and planning A: Economy and Space, 41(9), 21252142. 
International Journal of Mathematical, Engineering and Management Sciences

Vol. 5, No. 6, 1014-1031, 2020

https://doi.org/10.33889/IJMEMS.2020.5.6.078

Branco, M.C., \& Rodrigues, L.L. (2006). Corporate social responsibility and resource-based perspectives. Journal of Business Ethics, 69(2), 111-132.

Brockhoff, K., Chakrabarti, A.K., \& Kirchgeorg, M. (1999). Corporate strategies in environmental management. Research-Technology Management, 42(4), 26-30.

Carmona-Moreno, E., Céspedes-Lorente, J., \& De Burgos-Jiménez, J. (2004). Environmental strategies in Spanish hotels: contextual factors and performance. The Service Industries Journal, 24(3), 101-130.

Chan, E., \& Lee, G.K. (2008). Critical factors for improving social sustainability of urban renewal projects. Social Indicators Research, 85(2), 243-256.

Chan, E.S., Hon, A.H., Chan, W., \& Okumus, F. (2014). What drives employees' intentions to implement green practices in hotels? The role of knowledge, awareness, concern and ecological behaviour. International Journal of Hospitality Management, 40, 20-28.

Chartered institute of personnel and development (CIPD) (2007). The environment and people management. Retrieved from https://www.cipd.co.uk/Images/annual-report_2007-8_tcm18-11764.pdf.

Chen, J.C., Silverthorne, C., \& Hung, J.Y. (2006). Organization communication, job stress, organizational commitment, and job performance of accounting professionals in Taiwan and America. Leadership \& Organization Development Journal, 27(4), 242-249.

Clarke, E. (2006). People management. Power Brokers, 12(10), 40-42.

Cohen, E., Taylor, S., \& Muller-Camen, M. (2012). HRM's role in corporate social and environmental sustainability. SHRM Report, 1, 1-16. Retrieved from https://www.shrm.org/hr-today/trends-andforecasting/special-reports-and-expert-views/Documents/Corporate-Social-EnvironmentalSustainability.pdf.

Collison, D.J., Cobb, G., Power, D.M., \& Stevenson, L.A. (2008). The financial performance of the FTSE4Good indices. Corporate Social Responsibility and Environmental Management, 15(1), 14-28.

Cook, J., \& Seith, B.J. (1992). Designing an effective environmental EMS training program. Journal of Environmental Regulation, 2(1), 53-62.

Copus, A.K., \& Crabtree, J.R. (1996). Indicators of socio-economic sustainability: an application to remote rural Scotland. Journal of Rural Studies, 12(1), 41-54.

Crane, A., Matten, D., \& Moon, J. (2008). Ecological citizenship and the corporation: politicizing the new corporate environmentalism. Organization \& Environment, 21(4), 371-389.

Crosbie, L., \& Knight, K. (1995). Strategy for sustainable business: environmental opportunity and strategic choice. McGraw-Hill, London, pp196-211.

Daily, B.F., \& Huang, S.C. (2001). Achieving sustainability through attention to human resource factors in environmental management. International Journal of Operations \& Production Management, 21(12), 1539-1552.

Daily, B.F., Bishop, J.W., \& Massoud, J.A. (2012). The role of training and empowerment in environmental performance: a study of the Mexican maquiladora industry. International Journal of Operations \& Production Management, 32(5), 631-647.

Daily, C.M., Dalton, D.R., \& Cannella Jr, A.A. (2003). Corporate governance: decades of dialogue and data. Academy of Management Review, 28(3), 371-382.

De Prins, P., Van Beirendonck, L., De Vos, A., \& Segers, J. (2014). Sustainable HRM: bridging theory and practice through the' respect openness continuity (ROC)'-model. Management Revue, 25(4), 263-284. Doi: 10.1688/mrev-2014-04-Prins. 
International Journal of Mathematical, Engineering and Management Sciences

Vol. 5, No. 6, 1014-1031, 2020

https://doi.org/10.33889/IJMEMS.2020.5.6.078

Deepak, B., \& Prakash, T. (2015). Green HRM-A way to greening the environment. IOSR Journal of Business and Management, 17(12), 45-53.

Dempsey, N., Bramley, G., Power, S., \& Brown, C. (2011). The social dimension of sustainable development: defining urban social sustainability. Sustainable Development, 19(5), 289-300.

Ditz, D.W., Ranganathan, J., \& Banks, R.D. (1995). Green ledgers: case studies in corporate environmental accounting. World Resources Institute. Retrieved from: http://agris.fao.org/agrissearch/search.do?recordID=US9607583.

Driessen, E., Van, H.L., Don, F.J., Peen, J., Kool, S., Westra, D., Hendriksen, M., Schoevers, R.A., Cuijpers, P., Twisk, J.W.R., \& Dekker, J.J. (2013). The efficacy of cognitive-behavioral therapy and psychodynamic therapy in the outpatient treatment of major depression: a randomized clinical trial. American Journal of Psychiatry, 170(9), 1041-1050.

Ehnert I., Harry, W., \& Zink, K.J. (2014). Sustainability and HRM. In: Ehnert I., Harry W., Zink K. (eds) 425 Sustainability and Human Resource Management. Springer, Berlin, Heidelberg. pp 3-32.

Ehnert, I. (2009a). Sustainability and HRM. Sustainability and Human Resource Management (pp 3-32). Springer, Berlin, Heidelberg.

ehnert, i. (2009b). sustainable human Resource Management. A Conceptual and Exploratory Analysis from a Paradox Perspective (pp33-78). Physica-Verlag: Berlin/Heidelberg, Germany.

Ehnert, I. (2009c). Conceptual model for sustainable HRM and a Paradox Framework. In Sustainable Human Resource Management (pp163-181). Physica-Verlag HD.

Ehnert, I. (2009d). Sustainability and human resource management: reasoning and applications on corporate websites. European Journal of International Management, 3(4), 419-438.

Epstein, M.J. (2008). Making sustainability work: best practices in managing and measuring corporate social. Environmental and Economic Impacts, Greenleaf, Sheffield.

Erdogan, N., \& Baris, E. (2007). Environmental protection programs and conservation practices of hotels in Ankara, Turkey. Tourism Management, 28(2), 604-614.

Fayyazi, M., Shahbazmoradi, S., Afshar, Z., \& Shahbazmoradi, M.R. (2015). Investigating the barriers of the green human resource management implementation in oil industry. Management Science Letters, 5(1), 101-108.

Fernández, E., Junquera, B., \& Ordiz, M. (2003). Organizational culture and human resources in the environmental issue: a review of the literature. International Journal of Human Resource Management, 14(4), 634-656.

Gadenne, D.L., Kennedy, J., \& McKeiver, C. (2009). An empirical study of environmental awareness and practices in SMEs. Journal of Business Ethics, 84(1), 45-63.

Garza-Reyes, J.A. (2015). Lean and green-a systematic review of the state of the art literature. Journal of Cleaner Production, 102(1), 18-29.

Garza-Reyes, J.A., Salomé Valls, A., Nadeem, S.P., Anosike, A., \& Kumar, V. (2019). A circularity measurement toolkit for manufacturing SMEs. International Journal of Production Research, 57(23), 7319-7343.

Gill, J.D., Crosby, L.A., \& Taylor, J.R. (1986). Ecological concern, attitudes, and social norms in voting behavior. Public Opinion Quarterly, 50(4), 537-554.

Glaser, M., \& Diele, K. (2004). Asymmetric outcomes: assessing central aspects of the biological, economic and social sustainability of a mangrove crab fishery, Ucides cordatus (Ocypodidae), in North Brazil. Ecological Economics, 49(3), 361-373. 
International Journal of Mathematical, Engineering and Management Sciences

Vol. 5, No. 6, 1014-1031, 2020

https://doi.org/10.33889/IJMEMS.2020.5.6.078

Gollan, P.J., \& Xu, Y. (2014). Fostering corporate sustainability. In: Ehnert, I., Harry, W., \& Zink, K. (eds) Sustainability and Human Resource Management. CSR, Sustainability, Ethics \& Governance. Springer, Berlin, Heidelberg, pp. 225-245.

Gollan, P.J. (2000). Human resources, capabilities and sustainability. In: Dunphy, D., Benveniste, J., Griffiths, A., \& Sutton, P. (eds.) Sustainability: The Corporate Challenge for the 21st Century. Allen and Unwin, Crows Nest, NSW, Australia, pp. 55-77.

González-Benito, J., \& González-Benito, Ó. (2005). Environmental proactivity and business performance: an empirical analysis. Omega, 33(1), 1-15.

Govindan, K., Kannan, D., \& Shankar, K.M. (2014). Evaluating the drivers of corporate social responsibility in the mining industry with multi-criteria approach: a multi-stakeholder perspective. Journal of Cleaner Production, 84, 214-232.

Govindarajulu, N., \& Daily, B.F. (2004). Motivating employees for environmental improvement. Industrial Management \& Data Systems, 104(4), 364-372.

Graves, L.M., Sarkis, J., \& Zhu, Q. (2013). How transformational leadership and employee motivation combine to predict employee pro-environmental behaviours in China. Journal of Environmental Psychology, 35, 81-91.

Griessler, E., \& Littig, B. (2005). Social sustainability: a catchword between political pragmatism and social theory. International Journal for Sustainable Development, 8(1/2), 65-79.

Guerci, M., \& Shani, A.B. (2013). Moving toward stakeholder-based HRM: a perspective of Italian HR managers. The International Journal of Human Resource Management, 24(6), 1130-1150.

Guerci, M., Longoni, A., \& Luzzini, D. (2016). Translating stakeholder pressures into environmental performance-the mediating role of green HRM practices. The International Journal of Human Resource Management, 27(2), 262-289.

Hanegraaf, M.C., \& Biewinga, E.E. (1998). Assessing the ecological and economic sustainability of energy crops. Biomass and Bioenergy, 15(4-5), 345-355.

Harris, L.C., \& Ogbonna, E. (1998). Employee responses to culture change efforts. Human Resource Management Journal, 8(2), 78-92.

Harvey, G., Williams, K., \& Probert, J. (2013). Greening the airline pilot: HRM and the green performance of airlines in the UK. The International Journal of Human Resource Management, 24(1), 152-166.

Hillary, R. (2004). Environmental management systems and the smaller enterprise. Journal of Cleaner Production, 12(6), 561-569.

Ilinitch, A.Y., Soderstrom, N.S., \& Thomas, T.E. (1998). Measuring corporate environmental performance. Journal of Accounting and Public Policy, 17(4-5), 383-408.

Jabbour, C.J.C. (2013). Environmental training in organisations: from a literature review to a framework for future research. Resources, Conservation and Recycling, 74, 144-155.

Jabbour, C.J.C. (2015). Environmental training and environmental management maturity of Brazilian companies with ISO14001: empirical evidence. Journal of Cleaner Production, 96, 331-338.

Jabbour, C.J.C., \& de Sousa Jabbour, A.B.L. (2016). Green human resource management and green supply chain management: linking two emerging agendas. Journal of Cleaner Production, 112, 1824-1833.

Jabbour, C.J.C., \& Santos, F.C.A. (2008a). Relationships between human resource dimensions and environmental management in companies: proposal of a model. Journal of Cleaner Production, 16(1), 51-58. 
International Journal of Mathematical, Engineering and Management Sciences

Vol. 5, No. 6, 1014-1031, 2020

https://doi.org/10.33889/IJMEMS.2020.5.6.078

Jabbour, C.J.C., \& Santos, F.C.A. (2008b). The central role of human resource management in the search for sustainable organizations. The International Journal of Human Resource Management, 19(12), 21332154.

Jabbour, C.J.C., Santos, F.C.A., \& Nagano, M.S. (2010). Contributions of HRM throughout the stages of environmental management: methodological triangulation applied to companies in Brazil. The International Journal of Human Resource Management, 21(7), 1049-1089.

Jackson, S.E., Schuler, R.S., \& Jiang, K. (2014). An aspirational framework for strategic human resource management. The Academy of Management Annals, 8(1), 1-56.

Jafri, S. (2012). Green HR practices: an empirical study of certain automobile organizations of India. Human Resource Management, 42, 6193-6198.

Järlström, M., Saru, E., \& Vanhala, S. (2018). Sustainable human resource management with salience of stakeholders: a top management perspective. Journal of Business Ethics, 152(3), 703-724.

Jepsen, D.M., \& Grob, S. (2015). Sustainability in recruitment and selection: building a framework of practices. Journal of Education for Sustainable Development, 9(2), 160-178.

Jha, R., Gaiha, R., \& Pandey, M.K. (2013). Body mass index, participation, duration of work and earnings under the national rural employment guarantee scheme: evidence from Rajasthan. Journal of Asian Economics, 26, 14-30.

Jones, P., Hillier, D., \& Comfort, D. (2014). Sustainability in the global hotel industry. International Journal of Contemporary Hospitality Management, 26(1), 5-17.

Jones, T.M., \& Felps, W. (2013). Stakeholder happiness enhancement: a neo-utilitarian objective for the modern corporation. Business Ethics Quarterly, 23(3), 349-379.

Kesidou, E., \& Demirel, P. (2012). On the drivers of eco-innovations: empirical evidence from the UK. Research Policy, 41(5), 862-870.

Kramar, R. (2014). Beyond strategic human resource management: is sustainable human resource management the next approach. The International Journal of Human Resource Management, 25(8), 1069-1089.

Laudal, T. (2011). Drivers and barriers of CSR and the size and internationalization of firms. Social Responsibility Journal, 7(2), 234-256.

Linnenluecke, M.K., \& Griffiths, A. (2010). Corporate sustainability and organizational culture. Journal of World Business, 45(4), 357-366.

Longoni, A., Golini, R., \& Cagliano, R. (2014). The role of new forms of work organization in developing sustainability strategies in operations. International Journal of Production Economics, 147, 147-160.

Love, P.E., \& Gunasekaran, A. (1997). Process reengineering: a review of enablers. International Journal of Production Economics, 50(2-3), 183-197.

Mahmood, A., Sandhu, M.A., Kanwal, S., \& Iqbal, J. (2016). The effect of green HRM practices on sustainability: evidence from manufacturing companies in Pakistan. Pakistan Journal of Social Sciences (PJSS), 36(1), 177-188.

Mampra, M. (2013, January). Green HRM: does it help to build a competitive service sector? a study. In Proceedings of Tenth AIMS International Conference on Management (pp. 1273-1281), AIMS International, Banglore, India

Mariappanadar, S., \& Kramar, R. (2014). Sustainable HRM: the synthesis effect of high performance work systems on organisational performance and employee harm. Asia-Pacific Journal of Business Administration, 6(3), 206-224. 
International Journal of Mathematical, Engineering and Management Sciences

Vol. 5, No. 6, 1014-1031, 2020

https://doi.org/10.33889/IJMEMS.2020.5.6.078

Martin-Alcazar, F., Romero-Fernandez, P.M., \& Sánchez-Gardey, G. (2005). Strategic human resource management: integrating the universalistic, contingent, configurational and contextual perspectives. The International Journal of Human Resource Management, 16(5), 633-659.

Masri, H.A., \& Jaaron, A.A. (2017). Assessing green human resources management practices in Palestinian manufacturing context: an empirical study. Journal of Cleaner Production, 143, 474-489.

Mehta, K., \& Chugan, P.K. (2015). Green HRM in pursuit of environmentally sustainable business. Universal Journal of Industrial and Business Management, 3(3), 74-81.

Milliman, J. \& Clair, J. (1996), Best Environmental HRM Practices in the USA, In Wehrmeyer, W. (eds), Greening People - Human Resources and Environmental Management, Greenleaf Publishing, Sheffield. pp 49-74

Mittal, V.K., \& Sangwan, K.S. (2014). Prioritizing drivers for green manufacturing: environmental, social and economic perspectives. Procedia CIRP, 15, 135-140.

Molina-Azorín, J.F., Claver-Cortés, E., López-Gamero, M.D., \& Tarí, J.J. (2009). Green management and financial performance: a literature review. Management Decision, 47(7), 1080-1100.

Mostafa, M.M. (2006). Antecedents of Egyptian consumers' green purchase intentions: a hierarchical multivariate regression model. Journal of International Consumer Marketing, 19(2), 97-126.

Munasinghe, M. (1993). Environmental economics and biodiversity management in developing countries. Ambio, 22(2/3), 126-135.

Murillo-Luna, J.L., Garcés-Ayerbe, C., \& Rivera-Torres, P. (2007). What prevents firms from advancing in their environmental strategy?. International Advances in Economic Research, 13(1), 35-46.

Nadeem, S.P., Garza-Reyes, J.A., \& Glanville, D. (2018). The challenges of the circular economy. In Conway, E., \& Byrne, D. (eds.) Contemporary Issues in Accounting. Palgrave Macmillan, Cham, Switzerland. pp. 37-60.

Nadeem, S.P., Garza-Reyes, J.A., Anosike, A.I., \& Kumar, V. (2017). Spectrum of circular economy and its prospects in logistics. In Proceedings of the 2017 International Symposium on Industrial Engineering and Operations Management (IEOM) (pp. 440-451). Bristol, UK.

Nadeem, S.P., Garza-Reyes, J.A., Kumar, V., \& Anosike, A.I. (2019). Coalescing the lean and circular economy. Proceedings of the 9th International Conference on Industrial Engineering and Operations Management (IEOM) (pp. 1-12). Michigan: IEOM Society, Bangkok, Thailand.

North, K. (1997). Environmental business management: an introduction. International Labour Organization, Switzerland.

Oates, A. (2017). Industrial Relations and the Environment in the UK 1. In Wehrmeyer, W. (ed), Greening People. Routledge, New York, USA. pp. 117-140.

Opatha, H.H.P., \& Arulrajah, A.A. (2014). Green human resource management: simplified general reflections. International Business Research, 7(8), 101-112.

Orlitzky, M., Schmidt, F.L., \& Rynes, S.L. (2003). Corporate social and financial performance: a metaanalysis. Organization Studies, 24(3), 403-441.

Paille, P., Chen, Y., Boiral, O., \& Jin, J. (2013). The impact of human resource management on environmental. Pakistan Journal of Social Sciences, 36 (1), 177-188.

Paillé, P., Chen, Y., Boiral, O., \& Jin, J. (2014). The impact of human resource management on environmental performance: an employee-level study. Journal of Business Ethics, 121(3), 451-466.

Peneda Saraiva, P., \& Serrasqueiro, Z.M.S. (2007). Corporate sustainability in the Portuguese financial institutions. Social Responsibility Journal, 3(2), 82-94. 
International Journal of Mathematical, Engineering and Management Sciences

Vol. 5, No. 6, 1014-1031, 2020

https://doi.org/10.33889/IJMEMS.2020.5.6.078

Peng, Y.S., \& Lin, S.S. (2008). Local responsiveness pressure, subsidiary resources, green management adoption and subsidiary's performance: evidence from Taiwanese manufactures. Journal of Business Ethics, 79(1-2), 199-212.

Phillips, L. (2007). Go green to gain the edge over rivals. People Management, 13(17), 9.

Prasad, R.S. (2013). Green HRM-partner in sustainable competitive growth. Journal of Management Sciences and Technology, 1(1), 15-18.

Ramus, C.A. (2001). Organizational support for employees: encouraging creative ideas for environmental sustainability. California Management Review, 43(3), 85-105.

Ramus, C.A. (2002). Encouraging innovative environmental actions: what companies and managers must do. Journal of World Business, 37(2), 151-164.

Rawashdeh, A. (2018). The impact of green human resource management on organizational environmental performance in Jordanian health service organizations. Management Science Letters, 8(10), 1049-1058.

Renwick, D.W., Redman, T., \& Maguire, S. (2013). Green human resource management: a review and research agenda. International Journal of Management Reviews, 15(1), 1-14.

Revill, C. (2000). The "Greening” of personnel. human resource management an assessment. International Journal of Applied HRM, 1(3), 1-30.

Rompa, I. (2011). Explorative research on sustainable human resource management. Master's Thesis. University of Amsterdam.

Roy, M., \& Khastagir, D. (2016). Exploring role of green management in enhancing organizational efficiency in petro-chemical industry in India. Journal of Cleaner Production, 121, 109-115.

Russo, M.V., \& Fouts, P.A. (1997). A resource-based perspective on corporate environmental performance and profitability. Academy of Management Journal, 40(3), 534-559.

Sathyapriya, J., Kanimozhi, R., \& Adhilakshmi, V. (2013). Green HRM-Delivering high performance HR systems. International Journal of Marketing and Human Resource Management, 4(2), 19-25.

Sawang, S., \& Kivits, R.A. (2014). Greener workplace: understanding senior management's adoption decisions through the theory of planned behaviour. Australasian Journal of Environmental Management, 21(1), 22-36.

Schaltegger, S., \& Wagner, M. (2006). Integrative management of sustainability performance, measurement and reporting. International Journal of Accounting, Auditing and Performance Evaluation, 3(1), 1-19.

Seidel, S., Recker, J.C., Pimmer, C., \& vom Brocke, J. (2010). Enablers and barriers to the organizational adoption of sustainable business practices. In Proceeding of the 16th Americas Conference on Information Systems: Sustainable IT Collaboration Around the Globe (pp. 1-10). Association for Information Systems, United States.

Sena, J., \& Shani, A.R. (2008). Utilizing technology to support sustainability. In: Docherty, P., \& Mira kira, A.B. (eds) Creating Sustainable Work Systems. Routledge, London. pp. 110-126.

Smith, P.C. (2000). Sustainability and urban design. In: Wong, W.C., \& Chan, E.H.W. (eds) Building Hong Kong: Environmental Considerations. Hong Kong University Press, Hong Kong, pp. 17-42.

Sosik, J.J., Avolio, B.J., \& Jung, D.I. (2002). Beneath the mask: examining the relationship of selfpresentation attributes and impression management to charismatic leadership. The Leadership Quarterly, 13(3), 217-242.

Stiglitz, J.E. (2002). Employment, social justice and societal well-being. International Labour Review, 141(1-2), 9-29. 
International Journal of Mathematical, Engineering and Management Sciences

Vol. 5, No. 6, 1014-1031, 2020

https://doi.org/10.33889/IJMEMS.2020.5.6.078

Stringer, L. (2010). The green workplace: sustainable strategies that benefit employees, the environment, 642 and the bottom line. St. Martin's Press, New York, USA

Sweeney, L. (2009). A study of current practice of corporate social responsibility (CSR) and an examination of the relationship between CSR and financial performance using structural equation modelling (SEM). Doctoral Thesis, Dublin Institute of Technology, Dublin.

Tabatabaei, S.A.N., Omran, E.S., Hashemi, S., \& Sedaghat, M. (2017). Presenting sustainable HRM model based on balanced scorecard in knowledge-based ICT companies (The Case of Iran). Economics \& Sociology, 10(2), 107-124.

Teck Hui, L. (2008). Combining faith and CSR: a paradigm of corporate sustainability. International Journal of Social Economics, 35(6), 449-465.

Teixeira, A.A., Jabbour, C.J.C., \& de Sousa Jabbour, A.B.L. (2012). Relationship between green management and environmental training in companies located in Brazil: a theoretical framework and case studies. International Journal of Production Economics, 140(1), 318-329.

Thom, N., Zaugg, R.J. (2004). Nachhaltiges und innovatives personal management. In: Schwarz, E.J. (ed) Nachhaltiges Innovations Management (pp. 215-245). Gabler Verlag, Wiesbaden.

Tisdell, C. (1996). Economic indicators to assess the sustainability of conservation farming projects: an evaluation. Agriculture, Ecosystems \& Environment, 57(2-3), 117-131.

Tooranloo, H.S., Azadi, M.H., \& Sayyahpoor, A. (2017). Analyzing factors affecting implementation success of sustainable human resource management (SHRM) using a hybrid approach of FAHP and type-2 fuzzy DEMATEL. Journal of Cleaner Production, 162, 1252-1265.

Turkington, R., \& Sangster, K. (2006). From housing mix to social mix-housing's contribution to social sustainability. Town and Country Planning-London-Town and Country Planning Association, 75(6), 184.

Udokporo, C.K., Anosike, A., Lim, M., Nadeem, S.P., Garza-Reyes, J.A., \& Ogbuka, C.P. (2020). Impact of lean, agile and green (LAG) on business competitiveness: an empirical study of fast moving consumer goods businesses. Resources, Conservation and Recycling, 156, 104714.

Vincent, J.R. (1997). Resource depletion and economic sustainability in Malaysia. Environment and Development Economics, 2(1), 19-37.

Wagner, M. (2013). 'Green'human resource benefits: do they matter as determinants of environmental management system implementation?. Journal of Business Ethics, 114(3), 443-456.

Wehling, C., Guanipa Hernandez, A., Osland, J., Osland, A., Deller, J., Tanure, B., \& Sairaj, A. (2009). An exploratory study of the role of HRM and the transfer of German MNC sustainability values to Brazil. European Journal of International Management, 3(2), 176-198.

Wehrmeyer, W. (2017). Greening people: human resources and environmental management. Routledge, New York.

Williamson, D., Lynch-Wood, G., \& Ramsay, J. (2006). Drivers of environmental behaviour in manufacturing SMEs and the implications for CSR. Journal of Business Ethics, 67(3), 317-330.

Wolf, J. (2013). Improving the sustainable development of firms: the role of employees. Business Strategy and the Environment, 22(2), 92-108.

Wright, P.M., \& McMahan, G.C. (2011). Exploring human capital: putting 'human' back into strategic human resource management. Human Resource Management Journal, 21(2), 93-104.

Yadav, P.L., Han, S.H., \& Rho, J.J. (2016). Impact of environmental performance on firm value for sustainable investment: evidence from large US firms. Business Strategy and the Environment, 25(6), 402-420. 
International Journal of Mathematical, Engineering and Management Sciences

Vol. 5, No. 6, 1014-1031, 2020

https://doi.org/10.33889/IJMEMS.2020.5.6.078

Yeh, A.G.O., \& Ng, M.K. (2017). Planning for a better urban living environment in Asia. Routledge, New York.

Youndt, M.A., Snell, S.A., Dean Jr, J.W., \& Lepak, D.P. (1996). Human resource management, manufacturing strategy, and firm performance. Academy of Management Journal, 39(4), 836-866.

Yusoff, Y.M., \& Nejati, M. (2019). A conceptual model of green HRM adoption towards sustainability in hospitality industry. In Corporate Social Responsibility: Concepts, Methodologies, Tools, and Applications, IGI Global, Hershey, USA. pp. 400-421.

Zaugg, R.J., Blum, A., \& Thom, N. (2001). Sustainability in human resource management. Evaluation Report. Survey in European Companies and Institutions, Switzerland.

Original content of this work is copyright (c) International Journal of Mathematical, Engineering and Management Sciences. Uses under the Creative Commons Attribution 4.0 International (CC BY 4.0) license at https://creativecommons.org/licenses/by/4.0/ 